News. He concluded his remarks by saying he found it somewhat demeaning to go as a division representative to the association and, in essence, beg for our just due. He wondered if we might not explore the budget process, perhaps through the new Interdivisional Committee on Federation, and turn it around to where central headquarters would have to justify itself to the divisions instead of vice-versa.

Mr. Reason announced that a meeting was to be held that evening to discuss the formation of a New England Chapter of ACRL and that all interested nembers were invited to attend. $\mathrm{He}$ concluded by thanking the members and officers, particularly Mr. Shank, for their cooperation during his term of office, and then recognized Jordan M. Scepanski, who Moved a vote of gratitude and appreciation by the membership to Mr. J. Donald Thomas, former ACRL executive secretary, for his dedicated work during four years at headquarters. The motion was SECONDED from the floor and CARRIED by acclamation. Following this action, the meeting was adjourned.

\section{Contracts for Studies of Library Service}

The National Commission on Libraries and Information Science has awarded its first contracts for studies, totaling $\$ 52,000$ for fiscal year 1972 .

Dr. Frederick Burkhardt, chairman of the commission, said that "these contracts are the first steps towards an overall evaluation of library service in this country on all levels. The contracts cover a wide area of concern, and we hope to use these as a base for additional national planning efforts."

The studies to be done include: (1) preliminary investigation of present and potential library and information service needs contracted to the University of California (Berkeley) ; (2) an analysis for social, economic, and technical requirements for libraries and information services, 1975-1980, contracted to Dr. Edwin Parker, professor for Communication Research at Stanford University; (3) a study of funding sources for public libraries to be handled by the Public Administration Service, Chicago, Illinois; and (4) a feasibility study of centralized and regionalized interlibrary loan centers to be done through the Association of Research Libraries, Washington, D.C.

The study for the investigation of present and potential library and information service needs will be done through Charles Bourne who is director of the Institute of Library Re- search and professor, School of Librarianship, University of California, in Berkeley. The comprehensive working paper produced by this study will assist the commission in establishing its priorities in developing national planning for library and informational needs as charged by law. The intent of this study will be to identify needs for service on the part of various "publics" served and to see how the library and information community can best serve those needs.

Some of the major issues to be explored will be a review of the literature relating to the objectives and specifications for post-1975 library services and a survey and assessment of planning, methodology, and techniques that could be helpful. In this study preliminary identification and formulation of tentative specifications will be made for post-1975 information service.

In support of this paper, Dr. Parker, who is professor for Communication Research at Stanford University, shall prepare a comprehensive written document which will identify in specific terms the ways in which United States socialeconomic factors in 1975-1980 and advances in communications and information technology will have impact on the library and information needs of all types of citizens in various information-using roles. Dr. Parker's report will be available to the commission on January 1, 1973.

The Public Administration Service in Chicago has accepted a task for the commission to look at funding sources for public libraries. More than $\$ 800,000,000$ is spent on public libraries and library systems in America and much is known about how the money is spent. Too little is known about its sources. Some libraries obtain revenue from the smallest political areas served (the city, the town, the county), some from the largest (the state). Others obtain money from a combination of sources including municipal, county, region, state, federal, gifts, and endowments. No report of the full scope of fund resources is available, and the commission feels it is now needed.

This study will, Dr. Burkhardt hopes, "let public libraries all over America see where additional funds could be made available and how to get at the money which is so sorely needed by libraries and information centers all over America."

The National Commission on Libraries and Information Science has also contracted with the Association of Research Libraries in Washington for a feasibility study of centralized and regionalized interlibrary loan centers. This particular study will review the current literature, estimate the demand for interlibrary loans in the future, prepare an outline of methodology for a cost study of initial development of central and regional monograph lending centers, establish a professional committee to review recommendations, and to prepare a report to 


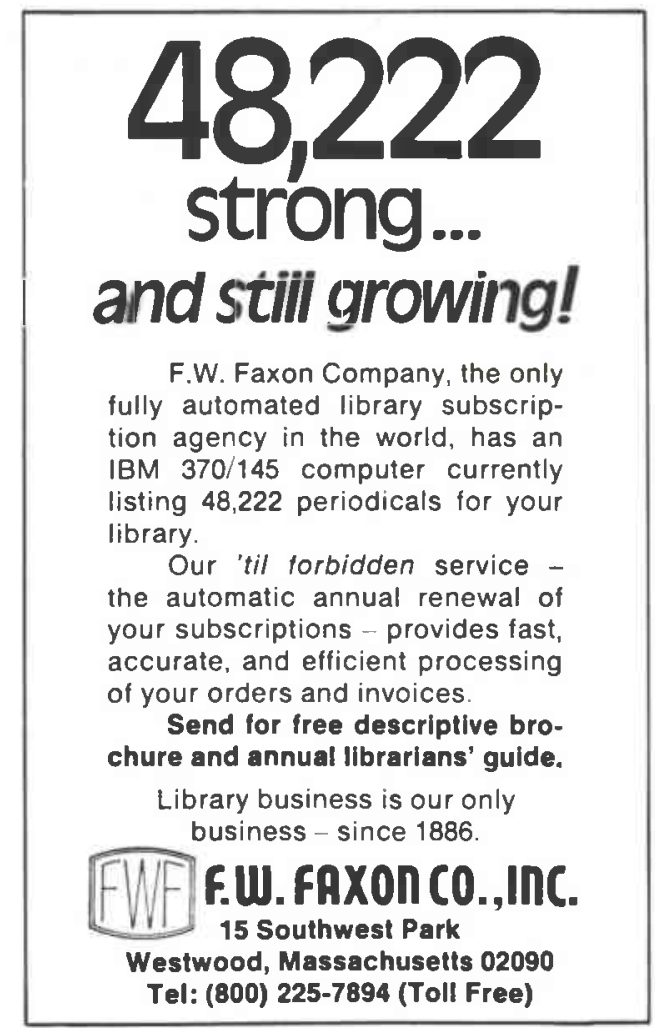

be available to the commission for a working paper, by the end of March 1973.

"These first positive steps on the part of the National Commission on Libraries and Information Science are merely the beginnings," said Dr. Burkhardt, "in providing guidance and leadership for the library community with which the Commission has been charged by the President of the U.S. and the U.S. Congress."

\section{ACRL SEEKS NOMINATIONS}

The ACRL Committee on Appointments and Nominations seeks the names of members interested in serving on committees during 1973/74. Recommendations for appointments to ACRL committees will be made to the president-elect shortly after the Midwinter Meeting in January. Individuals interested in committee work should be willing to attend both Midwinter and Annual Conference meetings during their terms. Candidates for the office of ACRL vice-president/president-elect will also be selected at this time. Members with an interest in serving or those who wish to recommend others should write to Ms. Johnnie Givens, Chairman of the ACRL Committee on Appointments and Nominations, Head Librarian, Austin Peay State University, Clarksville, TN 37040 .

\section{APPOINTMENT TO THE FACULTY OF THE GRADUATE LIBRARY SCHOOL, UNIVERSITY OF CHICAGO- A CONTINUOUS SEARCH FOR QUALIFIED CANDIDATES}

The Graduate Library School is engaged in a continuous search for candidates possessing qualities which indicate a strong potential for academic distinction and who may therefore be considered for appointment to its faculty; applications from all candidates who believe they can demonstrate these qualities are welcome.

The enrichment of teaching through an active research program is an important goal of the School. Evaluation of any applicant will be based in part on the nature and quality of his contributions to knowledge, as reflected in a doctoral dissertation or in research publications; these may be in fields other than librarianship. Reprints of research papers authored by the applicant are helpful in expediting the evaluation process.

Inquiries should be directed to: Dean, Graduate Library School, University of Chicago, Chicago, Illinois 60637. 